\title{
Effect of Guar Gum on the Physicochemical, Thermal, Rheological and Textural Properties of Green Edam Cheese
}

\author{
Nuno M. Oliveira • Fernando Q. Dourado • \\ António M. Peres - Marta V. Silva • João M. Maia • \\ José. A. Teixeira
}

Received: 23 March 2009 / Accepted: 18 January 2010 / Published online: 25 February 2010

(C) Springer Science+Business Media, LLC 2010

\begin{abstract}
In attempts to produce a low-fat cheese with a rheology and texture similar to that of a full-fat cheese, guar gum (within $0.0025-0.01 \%$; $w / v$, final concentration) was added to low-fat milk. The obtained cheeses were characterised regarding their physicochemical, thermal, rheological and textural properties. Control cheeses were also produced with low and full-fat milk. The physicochemical
\end{abstract}

N. M. Oliveira $\cdot$ F. Q. Dourado $(\bowtie) \cdot J$. A. Teixeira IBB - Institute for Biotechnology and Bioengineering, Centre for Biological Engineering, Universidade do Minho, Campus de Gualtar,

4710-057 Braga, Portugal

e-mail: fdourado@deb.uminho.pt

A. M. Peres

LSRE-Laboratory of Separation and Reaction Engineering,

Escola Superior Agrária, Instituto Politécnico de Bragança,

Campus Santa Apolónia,

5301-855 Bragança, Portugal

M. V. Silva

ISCSN, Instituto Superior de Ciências da Saúde-Norte,

Rua Central de Gandra, no 1317 ,

4585-116 Gandra (Paredes), Portugal

M. V. Silva

CEFT-Departamento de Engenharia Química,

Universidade do Porto,

Rua Dr. Roberto Frias, s/n,

4200-465 Porto, Portugal

\section{J. M. Maia}

Department of Polymer Engineering, University of Minho, Campus de Azurém,

4800-058 Guimarães, Portugal properties of the guar gum modified cheeses were similar to those of the low-fat control. No significant differences were detected in the thermal properties (concerning the enthalpy and profile of water desorption) among all types of cheeses. The rheological behaviour of the $0.0025 \%$ modified cheese was very similar to the full-fat control. Overall, no trend was observed in the texture profile (hardness, cohesiveness, gumminess and elasticity) of the modified cheeses versus guar gum concentration, as well as in comparison with the control groups, suggesting that none of the studied polysaccharide concentrations simulated the textural functions of fat in Edam cheese.

Keywords Edam cheese · Low fat · Guar gum · Rheology · Texture $\cdot$ Calorimetry

\section{Introduction}

There has been a growing interest in food products containing less fat, less cholesterol and lower calories, due to the increase of cardiovascular diseases, obesity and diabetes. Low-fat cheese is of interest to the consumers' choice in this regard.

The improvement of the conventional manufacturing techniques, the selective use of starter and adjunct cultures and the use of fat replacers summarise the three main technological approaches used for the modification of the physicochemical, textural and functional properties of the cheese while reducing the caloric value of the cheese. The last approach has been highly explored (Mistry 2001). 
Fat replacers are classified as fat mimetics and fat substitutes. Examples of fat mimetics are whey protein or carbohydrate-based products that mimic the properties of fat. They can improve the texture and yield of low-fat cheese through the increase of moisture. Fat substitutes are fat-based products that have similar physical and functional characteristics but lower caloric value than that of natural milk fat (Mistry 2001). Fat mimetics such as Simplesse ${ }^{\circledR}$ and Dairy-Lo ${ }^{\circledR}$, both whey protein concentrates, have been used for the manufacture of low-fat white pickled and lowfat Mozzarella cheese. Stellar ${ }^{\circledR}$, Novagel ${ }^{\circledR}$, OptaMax ${ }^{\circledR}$ and Versagel ${ }^{\circledR}$ are examples of carbohydrate-based products also used for the manufacture of low-fat Mozzarella (Kavas et al. 2004; Zisu and Shah 2005; Raju and Pal 2009).

Edam is one of Holland's most exported cheeses. This cheese is also highly manufactured in Portugal and commercialised under the trade name "Flamengo". Data from the Portuguese Institute of Statistics (INE) showed that in 2002, 30,335 tonnes of Flamengo cheese were manufactured, a volume representing in average, $60 \%$ of the total Portuguese cheese production. In that year, profits from the Portuguese Flamengo cheese market reached approximately 127 million $€$.

From a literature survey, few studies still exist on the use of fat replacers in commercial cheeses. This is especially the case with isolated biopolymers such as selected polysaccharides (Bullens et al. 1994; Kanombirira and Kailasapathy 1995; Kailasapathy 1998; Volikakis et al. 2004). Their individual use may allow a more quantified assessment of their effect on the final product and to better tailor the properties of the manufactured cheeses.

Guar gum, galactomannan, is a non-gelling neutral polysaccharide composed of a linear $(1 \rightarrow 4)-\beta$-D-mannan backbone with varying amounts of side chains. These consist of a single D-galactose unit, linked by $(1 \rightarrow 6)-\alpha$ glycosidic bonds to the backbone. These polysaccharides are commonly obtained from the seed endosperm of many leguminous seeds. Due to their different origins, the mannose/galactose $(\mathrm{M} / \mathrm{G})$ composition ratio can vary. The more substituted of the commercial galactomannans, guar gum, contains an $\mathrm{M} / \mathrm{G}$ of 1.8-2.1. Guar gum, derived from the endosperm of Cyamopsis tetragonolobus L. (a leguminous plant), has been widely used as a food additive due to its very high viscosity in aqueous media, even at low concentrations. It has been used also as a versatile thickener and/or stabiliser for ice cream, baked goods, sauces and beverages (Fox 1992; Srivastava and Kapoor 2005).

The purpose of this work was to evaluate the effect of different concentrations of guar gum on the physicochemical, rheological and textural properties of a low-fat Edam cheese. Results were interpreted in terms of evaluating if guar gum could be used as a fat mimetic in the manufacture of a low-fat Edam (Flamengo) cheese.

\section{Material and Methods}

\section{Materials}

Guar gum and calcium chloride $\left(\mathrm{CaCl}_{2}\right)$ were purchased from Sigma-Aldrich Química S.A. (Sintra, Portugal). Flora Danica (a freeze-dried mesophilic starter containing Lactococcus lactis subsp. lactis, L. lactis subsp. cremoris, L. lactis subsp. lactis biovar diacetylactis and Leuconostoc mesenteroides subsp. cremoris), Anatto color (an orangered dye) and Stabo 230 (a commercial enzyme solution containing approximately $85 \% v / v$ bovine pepsin and $15 \%$ $v / v$ chymosin) were a kind gift from Promolac-Comércio e Indústria de Produtos Lácteos Lda. (Barcarena, Portugal). Pasteurised low-fat $(0.4 \% \mathrm{w} / v$ fat $)$ and full-fat milk $(3.5 \%$ $w / v$ fat, taken from the manufacturer's description), were obtained from Lacticínios Vigor S.A. (Sintra, Portugal).

Figure 1 shows a summary of the experimental set-up used in this work.

\section{Preparation of Guar Gum Solutions}

A guar gum solution was prepared at room temperature as follows: $1 \% w / v$ guar was dissolved in distilled water by stirring vigorously for $10 \mathrm{~min}$ followed by overnight gentle stirring. The mixture was then centrifuged for $30 \mathrm{~min}$, at $3,200 \mathrm{~g}$ and $4^{\circ} \mathrm{C}$, to remove undissolved material. The

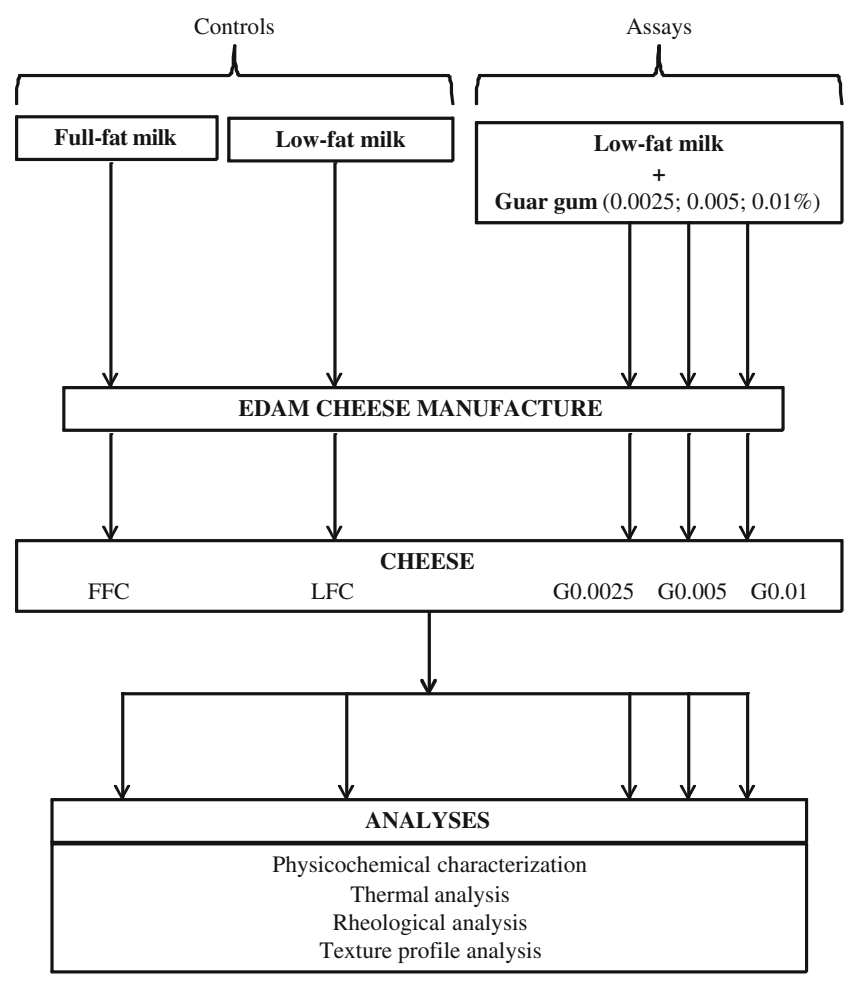

Fig. 1 Summary of the experimental design 
supernatant was recovered and three aliquots were withdrawn to determine the amount of soluble polysaccharides. This was done by the dry weight method, where the precipitates were placed in an oven at $105^{\circ} \mathrm{C}$ until a constant mass was recorded. A final $0.50 \% \pm 0.01 \mathrm{w} / v$ guar solution (G) was obtained. This solution was stored at $4{ }^{\circ} \mathrm{C}$ until use.

\section{Preparation of the Starter Culture}

Low- or full-fat milk was used, depending on the type of cheese being manufactured. Forty milliliters of sterilised milk $\left(121^{\circ} \mathrm{C}\right.$ for $\left.5 \mathrm{~min}\right)$ were inoculated with $0.4 \mathrm{~g}$ Flora Danica and incubated at $30^{\circ} \mathrm{C}$ for $16 \mathrm{~h}$. Several solutions were then prepared by inoculating $60 \mathrm{~mL}$ of sterilised milk with $0.6 \mathrm{~mL}$ of the incubated solution. These final solutions (starter cultures) were left at room temperature for $30 \mathrm{~min}$ and then stored at $-18^{\circ} \mathrm{C}$ until incubation.

Before the cheese manufacture, the starter cultures were incubated at $30^{\circ} \mathrm{C}$, for $16 \mathrm{~h}$.

\section{Edam Cheese Manufacture}

Two control groups consisting of a full-fat (FFC) and a low-fat cheese (LFC) were manufactured, each from 7.6 L full- or low-fat milk (depending on the type of cheese being manufactured) and $400 \mathrm{~mL}$ distilled $\mathrm{H}_{2} \mathrm{O}$. Three types of low-fat cheese were also manufactured by the addition of specific amounts of guar gum $(\mathrm{G}$, prepared as described in $2.2)$ to $7.6 \mathrm{~L}$ low-fat milk, before the pasteurization process: $\mathrm{G} 0.0025$, prepared by the addition of $40 \mathrm{~mL} \mathrm{G}$ and $360 \mathrm{~mL}$ distilled $\mathrm{H}_{2} \mathrm{O}, \mathrm{G} 0.005$, using $80 \mathrm{~mL} \mathrm{G}$ and $320 \mathrm{~mL}$ of distilled $\mathrm{H}_{2} \mathrm{O}$ and finally $\mathrm{G} 0.01$, by adding $160 \mathrm{~mL} \mathrm{G}$ and $240 \mathrm{~mL}$ of distilled $\mathrm{H}_{2} \mathrm{O}$. Each cheese group was manufactured on a different day.

For each type of cheese, the mixture was pasteurised at $62^{\circ} \mathrm{C}$ for $30 \mathrm{~min}$, under constant stirring. The mixture was then cooled and stabilised to $30^{\circ} \mathrm{C}$, followed by the addition of $60 \mathrm{~mL}$ starter culture (prepared as described in 2.3), $1.6 \mathrm{~g} \mathrm{CaCl}_{2}$ and $160 \mu \mathrm{L}$ Anatto color. The mixture was homogenised without applying any pressure and let to acidify for $30 \mathrm{~min}$, at $30^{\circ} \mathrm{C}$, without stirring. Afterwards, $3.5 \mathrm{~mL}$ Stabo 230 rennet was added. The mixture was homogenised and left to stand for $30 \mathrm{~min}$, at $30^{\circ} \mathrm{C}$, to coagulate of the casein. The obtained curd was then cut using vertical and horizontal wire cutters (having $1.5 \mathrm{~cm}$ spacing in between the wires) to promote syneresis. The curd was then left to settle for 20 minutes and then a fraction of the whey was removed (pre-drainage step). The temperature of the curd was raised to $38^{\circ} \mathrm{C}$ by the addition of $1 \mathrm{~L}$ sterile distilled water at $66^{\circ} \mathrm{C}$ (cooking step). This was followed by mixing for $20 \mathrm{~min}$, at $38^{\circ} \mathrm{C}$, with removal of the remaining whey afterwards. The curd was then compressed using a cylindrical mould according to the following sequence: $160 \mathrm{kPa}$ for $5 \mathrm{~min}, 260 \mathrm{kPa}$ for $15 \mathrm{~min}$ and $360 \mathrm{kPa}$ for $35 \mathrm{~min}$. The curd was then brined with $20 \% w / v \mathrm{NaCl}$ for $20 \mathrm{~h}$, at $10 \pm 1{ }^{\circ} \mathrm{C}$. The obtained cheese was finally stored at $10 \pm 1{ }^{\circ} \mathrm{C}$ and $100 \%$ relative humidity.

\section{Physicochemical Characterization}

For each type of cheese, a slice was cut (with approximately $0.5 \mathrm{~cm}$ thickness) along the full length of the cheese and manually triturated. Following this, the samples were promptly analysed. The moisture content was determined by the dry weight method. For this, $2.5 \mathrm{~g}$ were weighed (the exact value was recorded) into a container and placed in an oven at $102 \pm 2{ }^{\circ} \mathrm{C}$ until constant mass was obtained. Protein content was determined by the Kjeldahl method (AOAC 1980) and fat content by the Roese-Gottlieb method (AOAC 1980).

\section{Thermal Analysis}

Thermal analyses (TA) were done to compare the enthalpy and profile of water desorption among the different types of cheese (Dourado et al. 1999; 2002; Saldo et al. 2002). A thermogravimetrical analysis (TGA)-50 and a differential scanning calorimetry (DSC)-50 both from Shimadzu (Izasa, S.A., Portugal) was used. Acquisition of the results was done by TA-50WS software (version 1.14). Samples were collected from the central area of the cheeses and weighed $(20 \mathrm{mg}$; the exact masses were recorded) into aluminium pans (also from Izasa, S.A., Portugal). For the TGA, the pans were sealed with perforated lids to allow the release of evaporated water during the assays. Open pans were used for the DSC assays. Samples were heated over the temperature range $25-200^{\circ} \mathrm{C}$, at a scanning rate of $5^{\circ} \mathrm{C} \mathrm{min}^{-1}$.

\section{Rheological Analysis}

The elastic or storage modulus $\left(\mathrm{G}^{\prime}\right)$ and the viscous or loss modulus ( $\left.\mathrm{G}^{\prime \prime}\right)$ (Tunick 2000; Ma et al. 1997) were accessed using a StressTech Rheometer (Reologica Instruments AB, Lund, Sweden) bearing plate-plate surfaces with a diameter of 40 and $2 \mathrm{~mm}$ spacing between plates. Sandpaper (180 grit, purchased at a local store) was glued to the plate's surfaces to avoid slippage of the samples during the tests. Data was acquired by StressTech Rheometer software version 3.40 (Reologica Instruments $\mathrm{AB}$, Lund, Sweden). For each type of cheese a slice was cut along the full length of the cheese and a sample from the central region was collected (with a diameter of 40 and $2 \mathrm{~mm}$ thickness to fit the rheometer's plates). Tests were done at a constant stress 
of $1 \mathrm{kPa}$ with frequencies in the range $0.01-14.37 \mathrm{~Hz}$, at $25.0 \pm 0.1^{\circ} \mathrm{C}$.

\section{Texture Profile Analysis}

For each type of cheese, samples were cut with a cylindrical mould and the outer layers (approximately $5 \mathrm{~mm}$ thickness) sectioned and rejected, yielding samples with an average dimension of $19 \mathrm{~mm}$ in diameter and $15 \mathrm{~mm}$ in height. The samples were then left at room temperature for $30 \mathrm{~min}$ to obtain a thermal balance and then analysed. Texture profile analysis (Kanombirira and Kailasapathy 1995; Kailasapathy 1998; Lobato-Calleros et al. 2001) (TPA) was carried out with a Texture Analyzer, model TA-XT2 (Stable Micro Systems Ltd., Surrey, UK), equipped with a $5 \mathrm{~kg}$ load cell and a flat plunger $75 \mathrm{~mm}$ in diameter. The tests were done by compressing the sample until $80 \%$ of its initial height with two consecutive compressions, thus simulating two bites. The operating conditions were: pre-test speed of $2.0 \mathrm{~mm} / \mathrm{s}$, test speed of $1.0 \mathrm{~mm} / \mathrm{s}$, post-test speed of $10.0 \mathrm{~mm} / \mathrm{s}$, trigger type automatic, trigger force of $0.005 \mathrm{~N}$. Data acquisition was done using XTRA Dimension software, version 3.7G (Stable Micro Systems Ltd., Surrey, UK) at a rate of 25 points per second.

\section{Sampling and Statistical Analysis}

Each type of cheese was manufactured twice. From each replica, the physicochemical characterization and rheological analysis was done in triplicate while eight replicas were used for the TPA assays. Rheological analysis and TPA were both done after 7 days of storage. Moisture content was determined after 13 days of storage. The protein and fat content were both determined after 19 days of storage.

Descriptive statistics analysis was performed using SPSS (Statistical Package for Social Sciences) software for windows, version 17.0 (SPSS Inc., Chicago, IL). For each cheese type and frequencies, variables were expressed as the mean values \pm standard deviation (SD). All data were also analysed using the GLM (General Linear Model procedure) procedure for analysis of variance (ANOVA) with Type III sums of squares. When a significant Fstatistic was determined for a specific effect, means were analysed using Tukey's honestly significant difference multiple comparison test. The model used for the analysis of physicochemical data, thermal data and texture data included only the cheese type factor as a fixed effect (oneway ANOVA). The model used for the analysis of the rheological data used the oscillatory frequency and the cheese type as fixed effects, and their interaction (two-way ANOVA). A value $P<0.05$ was chosen for statistical significance.

\section{Results and Discussion}

Physicochemical Characterization

LFC is a general term that refers to cheeses whose fat content is lower than its corresponding full-fat variety. As the fat content of cheese is lowered, moisture content increases and protein plays a greater role in texture development. To counter this, the moisture in nonfat substance of cheese is generally equal to that in full-fat cheese (Mistry 2001).

The obtained values for moisture, fat and protein are summarised in Table 1 for each cheese type. To better interpret the effect of guar gum concentration on the physicochemical parameters of the manufactured cheeses, protein and fat values were expressed on a dry basis.

Compositional data for the several manufactured cheeses reflect how overall moisture and protein contents were increased when fat content was reduced. LFC had a higher moisture content than that of FFC and G0.01 and G0.005 had a similar moisture to that of LFC. However, no trend was noted for the gum concentration versus fat content among the modified cheeses and FFC.

As compared to the FFC, the protein increase of the lowfat cheeses was in the same proportion $(\sim 83 \%)$ as that of the fat reduction. LFC had a higher protein content than that of FFC, being similar to the protein contents of G0.01, G0.005 and G0.0025. This suggests that, as with the fat content, the addition of guar gum to a low-fat cheese bears no significant effect on the protein content.

The inverse relationship between guar concentration and moisture can be tentatively explained as follows: guar gum is known to exhibit the behaviour of a macromolecular solution, the properties of which are governed by topological entanglements (Robinson et al. 1982; Clark and Ross-Murphy 1987).

Table 1 Results (means \pm SD) of moisture, fat content and protein content for each cheese type

\begin{tabular}{lrrr}
\hline Cheese type & Moisture (\%) & \multicolumn{1}{c}{ Fat (\%d.b) } & Protein (\%d.b) \\
\hline FFC & $57.9 \pm 0.5 \mathrm{a}$ & $40.9 \pm 0.7 \mathrm{~b}$ & $32.0 \pm 0.4 \mathrm{a}$ \\
LFC & $65.7 \pm 0.3 \mathrm{~b}$ & $8.0 \pm 0.5 \mathrm{a}$ & $59.5 \pm 0.5 \mathrm{~b}$ \\
G0.01 & $64.3 \pm 1.0 \mathrm{~b}$ & $7.7 \pm 0.2 \mathrm{a}$ & $58.7 \pm 1.7 \mathrm{~b}$ \\
G0.005 & $65.9 \pm 0.4 \mathrm{~b}$ & $7.1 \pm 0.2 \mathrm{a}$ & $57.2 \pm 0.5 \mathrm{~b}$ \\
G0.0025 & $68.1 \pm 0.9 \mathrm{c}$ & $7.0 \pm 0.1 \mathrm{a}$ & $58.4 \pm 0.2 \mathrm{~b}$ \\
$P$ value $^{\mathrm{a}}$ & $<0.001$ & $<0.001$ & $<0.001$ \\
\hline
\end{tabular}

d.b. dry basis

${ }^{a} P$ values are those for the effect of 'cheese type' from one-way ANOVA analysis. If there was a significant effect of 'cheese type' on the physicochemical measures, then means were compared using Tukey's HSD post-hoc test

Lower case letters ( $a, b$ and $c)$ within a column are means without a common letter differ, $P<0.05$ 


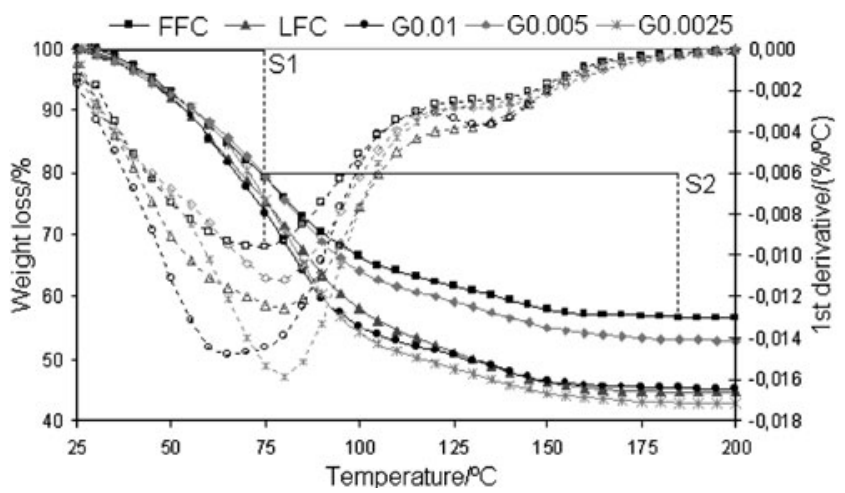

Fig. 2 Thermogravimetric curves for each cheese type. Weight loss (solid lines and symbols) and corresponding first derivatives (dotted lines and open symbols). Representation of the two distinct stages of water desorption, for FFC cheese, where the free water (S1) and bound water (S2) are marked

At the natural $\mathrm{pH}$ of milk, the negatively charged casein is unlikely to significantly interact with the neutral galactomannans (Bourriot et al. 1999). During cheese manufacture, the $\mathrm{pH}$ progresses to the casein's isoelectric point, along with proteolysis thus exposing hydrophobic (neutral) residues. These effects may allow enhanced interaction (by entanglement) between the proteins and the galactomannans. As guar gum concentration increases, intermolecular interaction also increases, thereby creating a tighter three-dimensional matrix limiting the amount of water within.

The overall trends here observed were similar to the ones by Lobato-Calleros et al. (2001). These authors have manufactured low-fat Manchego cheeses with three commercial fat replacers consisting of a commercial mixture of low methoxyl pectin and sucrose, whey protein concentrate (Dairy-Lo ${ }^{\circledR}$ ) and microparticulated whey protein (Simplesse ${ }^{\circledR}$ D100).

Küçüköner and Haque (2003) have manufactured a low(17\% fat) and full-fat (27\% fat) Edam cheese. Following 6 months maturation, on a dry basis, the protein and fat content of their FFC were, respectively, 29\% and $47 \%$ higher than the ones shown in Table 1. As to their LFC, the protein and fat content were over $300 \%$ and $10 \%$ higher, respectively. The observed differences could be ascribed to variations in the manufacturing process and to the maturation (as in this work, no maturation was involved).

\section{Thermal Analysis}

Guar gum affected only the moisture content of the low-fat cheeses. In addition, differences were noted in the amount of moisture among the modified cheeses. It has been postulated that the solubility of guar gum is mediated by the mannose side chains (Srivastava and Kapoor 2005). Therefore, TA was used to evaluate if differences in the affinity of the galactomannan for the water molecules could be detected. DSC and TGA were used to draw the profiles of water desorption, during heating at a controlled rate (Fig. 2). Table 2 gathers the values from the enthalpy, the onset (initial), peak and endset (final) temperatures of the endothermal process of water desorption, for all types of cheeses, as obtained by DSC. Statistical analysis of the results revealed that only the Tpeak and Tendest temperatures varied significantly (with $P=0.001$ and $P=0.006$, respectively). The FFC held the lowest Tpeak temperature, while the guar gum modified cheeses had similar values among themselves. While G0.01 had a higher Tpeak value than that of LFC, the Tpeak values of the remaining low-fat cheeses were similar among themselves. The Tendset values for FFC, LCF, G0.01 and G0.005 were similar among themselves and lower than the one of G0.0025. The enthalpy of water desorption was also similar among the modified cheeses. This might suggest that, as the moisture content decreased (with the increase in guar concentration), this water could be more strongly adsorbed. Alternatively, the water might be strongly entrapped within the proteinpolysaccharide three-dimensional matrix (as above proposed, as guar gum concentration increased, the amount of water within the matrix decreased). To verify these hypotheses, TGA assays were performed.

By analysis of the first derivatives of the thermogravimetric curves (Fig. 2), two representative stages of water

Table 2 Values (means $\pm \mathrm{SD}$ ) of the endothermic peak obtained for each cheese type, in DSC analysis

\begin{tabular}{lcccc}
\hline Cheese type & Tonset ${ }^{\circ} \mathrm{C}$ & Tpeak ${ }^{\circ} \mathrm{C}$ & Tendset ${ }^{\circ} \mathrm{C}$ & $\Delta \mathrm{H}\left(\mathrm{J} / \mathrm{g}_{\mathrm{H} 2 \mathrm{O}}\right)$ \\
\hline FFC & $27.7 \pm 0.3$ & $58.1 \pm 0.8 \mathrm{a}$ & $80.7 \pm 0.1 \mathrm{a}$ & $685.7 \pm 63.5$ \\
$\mathrm{LFC}$ & $28.8 \pm 0.9$ & $62.3 \pm 1.1 \mathrm{~b}$ & $81.9 \pm 0.8 \mathrm{a}$ & $737.8 \pm 18.3$ \\
$\mathrm{G} 0.01$ & $28.3 \pm 1.2$ & $65.0 \pm 0.2 \mathrm{c}$ & $82.6 \pm 1.4 \mathrm{a}$ & $781.5 \pm 67.0$ \\
$\mathrm{G} 0.005$ & $27.9 \pm 0.5$ & $63.5 \pm 0.4 \mathrm{~b}, \mathrm{c}$ & $83.6 \pm 0.9 \mathrm{a}$ & $767.4 \pm 5.2$ \\
$\mathrm{G}^{0.0025}$ & $29.6 \pm 0.2$ & $64.4 \pm 0.1 \mathrm{~b}, \mathrm{c}$ & $87.6 \pm 1.2 \mathrm{~b}$ & $861.2 \pm 43.8$ \\
$P$ value $^{\mathrm{a}}$ & 0.184 & 0.001 & 0.006 & 0.087
\end{tabular}

${ }^{\text {a }} P$ values are those for the effect of 'cheese type' from one-way ANOVA analysis. If there was a significant effect of 'cheese type' on the thermal measures, then means were compared using Tukey's HSD post-hoc test

Lower case letters ( $\mathrm{a}, \mathrm{b}, \mathrm{c}$ and $\mathrm{d}$ ) within a column are means without a common letter differ, $P<0.05$ 


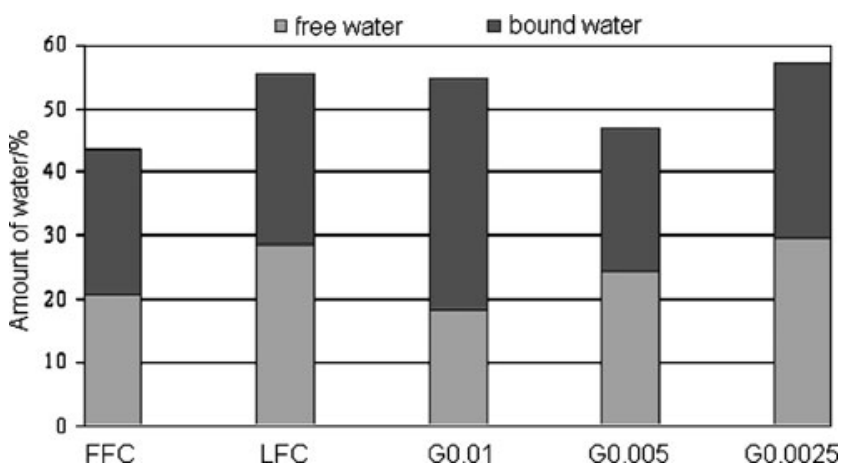

Fig. 3 Amount of free and bound water for each cheese type

desorption were differentiated. These were also observed by Saldo et al. (2002) for Garrotxa cheese. The first step of water loss (Fig. 2, S1) corresponded to free water, that is, water integrated within the cheese matrix but with a low binding energy. The second step of water desorption (Fig. 2, S2) was related to the more strongly associated water, i.e. bound water. The fraction of desorbed water from each stage was thus calculated (Fig. 3). From these results, an inverse relationship between guar concentration and the fraction of free water was noted, the lower guar concentration corresponding to the highest free water content. However, no correlation was detected for the fraction of bound water. These observations suggest that, in fact, increasing the guar gum concentration also increased the protein-polysaccharide interaction (chain entanglement). While this allowed the exclusion of more water during sineresis, the remaining free water was more strongly entrapped within the three-dimensional matrix.

\section{Rheological Analysis}

The rheological properties of mixed systems of galactomannans and proteins or polysaccharides have been studied by only a few researchers. In this work, the elastic or

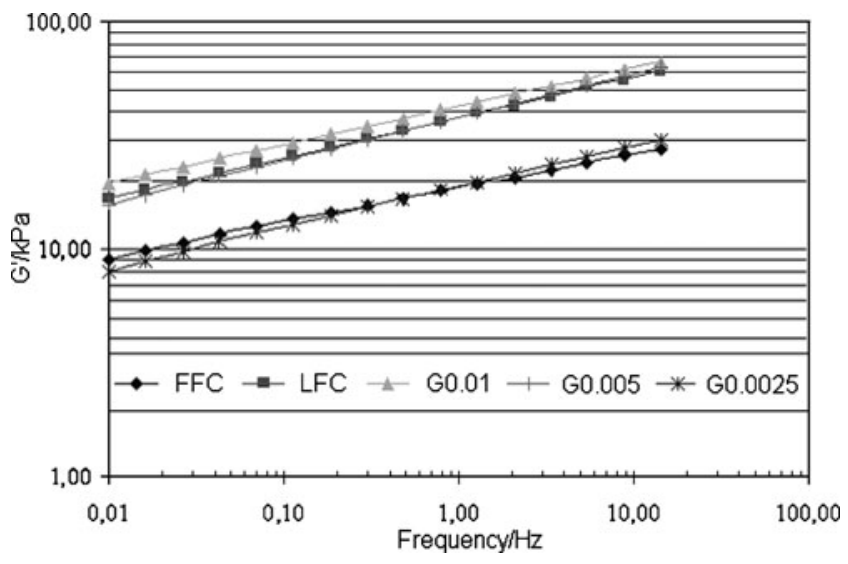

Fig. 4 Comparison of the storage modulus $\left(\mathrm{G}^{\prime}\right)$ for each cheese type, as a function of the applied frequency storage modulus $\left(\mathrm{G}^{\prime}\right)$ and the viscous or loss modulus $\left(\mathrm{G}^{\prime \prime}\right)$ were used for the rheological characterization of the different types of cheeses. Preliminary tests were done to determine the stress range for which linear viscoelastic behaviour occurred. From these, a stress value of $1 \mathrm{kPa}$ was chosen. In Figs. 4 and 5, a comparison of the rheological behaviour of the different types of cheeses was made. Values of $\mathrm{G}^{\prime}$ and $\mathrm{G}^{\prime \prime}$ were presented as a function of the oscillatory frequency in the interval $0.01-14.37 \mathrm{~Hz}$. In all cases, the magnitude of $\mathrm{G}^{\prime}$ values was always higher than $\mathrm{G}^{\prime \prime}$ values, indicating that weak gel or soft solid-type structures were present, and both parameters increased with frequency, as expected (e.g., Tunick 2000).

In Table 3, $\mathrm{G}^{\prime}$ and $\mathrm{G}^{\prime \prime}$ values from all samples are presented for $8.86,0.30$ and $0.01 \mathrm{~Hz}$. Within these results, a statistical comparison of the values was done, by means of a two-way ANOVA, considering two fixed effects (oscillatory frequency and cheese type) and its interaction. No significant 'oscillatory frequency $\times$ cheese type" interaction was detected for $\mathrm{G}^{\prime}(P=0.722)$ or $\mathrm{G}^{\prime \prime}(P=0.479)$.

Overall, the oscillatory frequency showed to be a significant effect $(P<0.001)$ for $\mathrm{G}^{\prime}$ and $\mathrm{G}^{\prime \prime}$, with the highest values of these modules being obtained at $8.86 \mathrm{~Hz}$. However, at 0.30 and $0.10 \mathrm{~Hz}, \mathrm{G}^{\prime}$ and $\mathrm{G}^{\prime \prime}$ values were similar. The LFC, G0.01 and G0.005 had similar and higher $\mathrm{G}^{\prime}$ values than those of the remaining cheeses. Yet, $\mathrm{G}^{\prime}$ values from LFC and G0.005 were also similar to those of FFC and G0.0025. As for the G" frequency values, LFC, G0.01 and G0.005 were statistically identical and higher than those of FFC and G0.0025, these being similar among themselves. Overall, $G^{\prime}$ values had a high standard deviation thus impossibilitating to evaluate which modified cheese simulated best the rheological properties of fat. The obtained results suggested that, $0.0025 \%$, guar gum seemed to simulate the best the rheological properties of fat in cheese manufactured with full-fat milk.

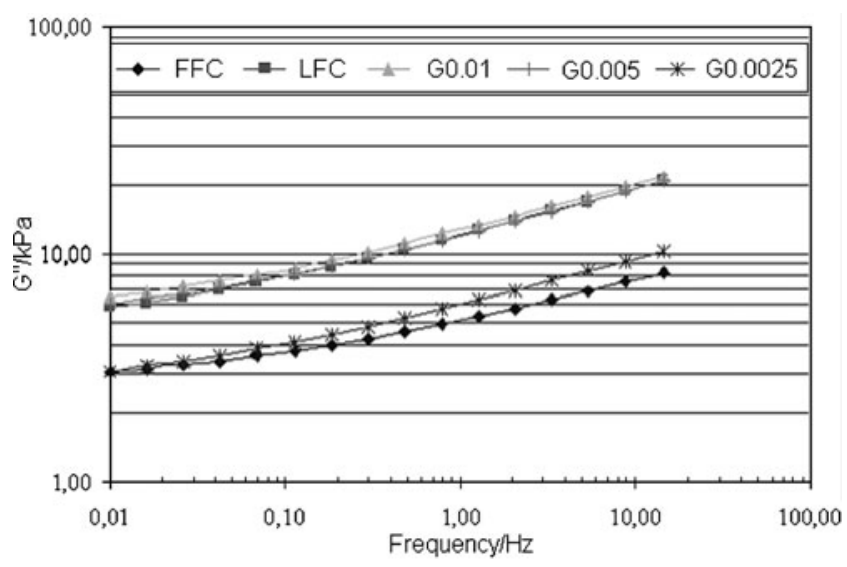

Fig. 5 Comparison of the loss modulus $\left(G^{\prime \prime}\right)$ for each cheese type, as a function of the applied frequency 
Table 3 Statistical comparison (means \pm SD) of the storage modulus $\left(\mathrm{G}^{\prime}\right)$ and loss modulus $\left(\mathrm{G}^{\prime \prime}\right)$ at selected shear frequencies, for each cheese type

\begin{tabular}{lcr}
\hline & $\mathrm{G}^{\prime} \mathrm{kPa}^{\mathrm{a}}$ & $\mathrm{G}^{\prime \prime} \mathrm{kPa}^{\mathrm{b}}$ \\
\hline Oscillatory frequency & & \\
$8.86 \mathrm{~Hz}$ & $45.6 \pm 23.1 \mathrm{~b}$ & $14.9 \pm 7.3 \mathrm{~b}$ \\
$0.30 \mathrm{~Hz}$ & $25.3 \pm 12.2 \mathrm{a}$ & $7.7 \pm 3.6 \mathrm{a}$ \\
$0.01 \mathrm{~Hz}$ & $13.8 \pm 6.7 \mathrm{a}$ & $4.9 \pm 2.2 \mathrm{a}$ \\
$P$ value & $<001$ & $<0.001$ \\
Cheese type & & \\
FFC & $16.8 \pm 8.4 \mathrm{a}$ & $4.9 \pm 2.1 \mathrm{a}$ \\
LFC & $34.3 \pm 17.5 \mathrm{a}, \mathrm{b}$ & $11.4 \pm 5.9 \mathrm{~b}$ \\
G0.01 & $38.5 \pm 30.8 \mathrm{~b}$ & $12.2 \pm 9.3 \mathrm{~b}$ \\
$\mathrm{G} 0.005$ & $34.4 \pm 18.6 \mathrm{a}, \mathrm{b}$ & $11.5 \pm 5.9 \mathrm{~b}$ \\
G0.0025 & $28.2 \pm 20.2 \mathrm{a}$ & $5.7 \pm 3.0 \mathrm{a}$ \\
$P$ value & 0.002 & $<0.001$ \\
\hline
\end{tabular}

a Oscillatory frequency $\times$ cheese type' interaction was not a significant $(P=0.722)$ source of variation for elastic or storage modulus $\left(\mathrm{G}^{\prime}\right)$

${ }^{\mathrm{b}}$ Oscillatory frequency $\times$ cheese type' interaction was not a significant $(P=0.479)$ source of variation for viscous or loss modulus $\left(\mathrm{G}^{\prime \prime}\right)$

' $P$ values are those for the effect of 'frequency' or 'cheese type' from 2-way ANOVA analysis. If there was a significant effect of 'frequency' or 'cheese type' on the rheological measures, then means were compared using Tukey's HSD post-hoc test

Lowercase letters ( $a$ and $b$ ) for each effect and within a column are means without a common letter differ, $P<0.05$

Interestingly, when $0.05 \%$ guar was added to low-fat milk, no cheese could be obtained. The formed curd had a very soft consistency, hindering whey removal and cheese moulding. High molecular weight polymers such as guar gum are known to form a gel network thus increasing the water holding ability (Ma et al. 1997). However, at high concentrations, rennet coagulation of low-fat milk could not be obtained due to the formation of large protein aggregates or an open network structure with large voids (Tan et al. 2007). These observations suggested the occurrence of a limiting guar concentration for the manufacture of low-fat Edam cheese.
An acceptable correlation existed between $\mathrm{G}^{\prime}$ and $\mathrm{G}^{\prime \prime}$ values and the moisture in the low-fat cheeses (being $R^{2}=$ 0.90 for $\mathrm{G}^{\prime}$ and $R^{2}=0.86$ for $\left.\mathrm{G}^{\prime \prime}\right)$, much higher than the one presented by Ma et al. (1997) $\left(R^{2}=0.50\right.$ for $\left.\mathrm{G}^{\prime}\right)$. In their work, they compared different types of fat replacers (carbohydrate and protein-based products) for Cheddar modification. However, a comparison between different concentrations of the same fat replacer was not done.

\section{Texture Profile Analysis}

Table 4 shows the results from the TPA. The presented parameters include hardness, cohesiveness, gumminess and elasticity. Analysing the four mechanical parameters, all low-fat cheeses had significantly higher values than those of FFC. Similar observations were also registered by Volikakis et al. (2004). The softer character of the FFC was expected as fat impedes the formation of a solid protein matrix and acts as lubricant, yielding a cheese with a higher smoothness and softness (Romieh et al. 2002). G0.005 and G0.0025 modified cheeses were softer (lower hardness values) than LFC. However, overall, no trend was noted for the textural parameters versus guar concentration which suggests that guar alone did not simulate well the textural properties of fat in cheese.

\section{Conclusion}

In this work, the effect of $0.0025 \%, 0.005 \%$, and $0.01 \%$ $(w / v)$ guar addition to low-fat milk before cheese manufacture was accessed. Compared with full-fat cheese, the modified ones had higher protein and moisture content and lower fat content. An inverse relationship was found between guar gum concentration and moisture content of the low-fat cheeses, the lower guar concentration corresponding to the highest moisture content. The rheological properties of the $0.0025 \% \mathrm{w} / \mathrm{v}$ guar gummodified cheese were proximal to the ones of the full-fat

Table 4 Results (means \pm SD) of hardness, cohesiveness, gumminess and elasticity for each cheese type

\begin{tabular}{lccrr}
\hline Cheese type & Hardness $(N)$ & Cohesiveness & Gumminess $(N)$ & \multicolumn{1}{c}{ Elasticity } \\
\hline FFC & $18.0 \pm 4.8 \mathrm{a}$ & $0.17 \pm 0.01 \mathrm{a}$ & $3.0 \pm 0.9 \mathrm{a}$ & $0.47 \pm 0.10 \mathrm{a}$ \\
$\mathrm{LFC}$ & $51.4 \pm 4.9 \mathrm{~d}$ & $0.23 \pm 0.02 \mathrm{~b}, \mathrm{c}$ & $12.0 \pm 1.6 \mathrm{c}$ & $0.77 \pm 0.07 \mathrm{~b}$ \\
$\mathrm{G} 0.01$ & $45.3 \pm 7.3 \mathrm{c}, \mathrm{d}$ & $0.22 \pm 0.01 \mathrm{~b}, \mathrm{c}$ & $10.1 \pm 1.7 \mathrm{~b}, \mathrm{c}$ & $0.75 \pm 0.11 \mathrm{~b}$ \\
$\mathrm{G} 0.005$ & $40.9 \pm 5.7 \mathrm{~b}, \mathrm{c}$ & $0.22 \pm 0.02 \mathrm{~b}$ & $8.9 \pm 1.5 \mathrm{~b}$ & $0.74 \pm 0.14 \mathrm{~b}$ \\
G0.0025 & $34.8 \pm 3.0 \mathrm{~b}$ & $0.24 \pm 0.02 \mathrm{c}$ & $8.4 \pm 1.0 \mathrm{~b}$ & $0.76 \pm 0.08 \mathrm{~b}$ \\
$P$-value $^{1}$ & $<0.001$ & $<0.001$ & $<0.001$ & $<0.001$ \\
\hline
\end{tabular}

a $P$ values are those for the effect of 'cheese type' from one-way ANOVA analysis. If there was a significant effect of 'cheese type' on the texture measures, then means were compared using Tukey's HSD post-hoc test

Lower case letters (a, b and c) within a column are means without a common letter differ, $P<0.05$ 
cheese. Finally, within the range of tested concentrations, guar gum alone did not simulate well the textural properties of fat in Edam cheese.

\section{References}

AOAC (1980) Official methods of analysis, 13th ed. In: W. Horwitz Association of Official Analytical Chemists. Arlington, VA. pp 376-384.

Bourriot, S., Garnier, C., \& Doublier, J.-L. (1999). Phase separation, rheology and microstructure of micellar casein-guar gum mixtures. Food Hydrocolloids, 13(1), 43-49.

Bullens, C., Krawczyk, G., \& Geithman, L. (1994). Reduced-fat cheese products using carrageenan and microcrystalline cellulose. Food Technology, 48(1), 79-81.

Clark, A. H., \& Ross-Murphy, S. B. (1987). Structural and mechanical properties of biopolymer gels. Advance in Polymer Science, 83, $55-192$.

Dourado, F., Mota, M., Pala, H., \& Gama, F. M. (1999). Effect of Cellulase adsorption on the surface and interfacial properties of cellulose. Cellulose, 6(4), 265-282.

Dourado, F., Bastos, M., Mota, M., \& Gama, F. M. (2002). Studies on the properties of Celluclast/Eudragit L-100 conjugate. Journal of Biotechnology, 99(2), 21-131.

Fox, J. E. (1992). Seed gums. In A. Imerson (Ed.), Thickening and gelling agents for food (pp. 153-170). Glasgow: Blackie.

INE (2002) Estatísticas Agro-Industriais - Leite e Derivados 19962000. In http://www.ine.pt/xportal/xmain?xpid=INE\&xpgid=ine publicacoes\&PUBLICACOESpub_boui=140523\&PUBLICACOES modo $=2$

Kailasapathy, K. (1998). Effect of adding carrageenan and gellan gums on yield and textural quality of Caerphilly cheese. Milchwissenschaft, 53(8), 446-449.

Kanombirira, S., \& Kailasapathy, K. (1995). Effects of interactions of carrageenan and gellan gum on yields, textural and sensory attributes of Cheddar cheese. Milchwissenschaft, 50(8), 452458.

Kavas, G., Oysun, G., Kinik, O., \& Uysal, H. (2004). Effect of some fat replacers on chemical, physical and sensory attributes of lowfat white pickled cheese. Food Chemistry, 88(3), 381-388.
Küçüköner, E., \& Haque, Z. U. (2003). Physico-chemical and rheological properties of full fat and low fat Edam cheeses. European Food Research and Technology, 217(3), 281-286.

Lobato-Calleros, C., Robles-Martinez, J. C., Caballero-Perez, J. F., \& Aguirre-Mandujano, E. (2001). Fat replacers in low-fat Mexican Manchego cheese. Journal of Texture Studies, 32(1), 1-14.

Ma, L., Drake, M. A., Barbosa-Cánovas, G. V., \& Swanson, B. G. (1997). Rheology of full-fat and low-fat Cheddar cheeses as related to type of fat mimetic. Journal of Food Science, 62(4), 748-752. Emmental cheese. Lait, 84, 343-358.

Mistry, V. V. (2001). Low fat cheese technology. International Dairy Journal, 11(4-7), 413-422.

Raju, N. P., \& Pal, D. (2009). The Physico-chemical, Sensory, and Textural Properties of Misti Dahi Prepared from Reduced Fat Buffalo Milk. Food and Bioprocess Technology, 2(1), 101-108.

Robinson, G., Ross-Murphy, S. B., \& Morris, E. R. (1982). Viscositymolecular weight relationships, intrinsic chains flexibility, and dynamic solution properties of guar galactomannan. Carbohydrate Research, 107(1), 17-32.

Romieh, E. A., Michaelidou, A., Biliaderis, C. G., \& Zerfiridis, G. K. (2002). Low-fat white-brined cheese made from bovine milk and two commercial fat mimetics: chemical, physical and sensory attributes. International Dairy Journal, 12(6), 525-540.

Saldo, J., Sendra, E., \& Guamis, B. (2002). Changes in water binding in high-pressure treated cheese, measured by TGA (thermogravimetrical analysis). Innovative Food Science and Emerging Technologies, 3 (3), 203-207.

Srivastava, M., \& Kapoor, V. P. (2005). Seed galactomannans: an overview. Chemistry \& Biodiversity, 2(3), 295-317.

Tan, Y. L., Ye, A., Singh, H., \& Hemar, Y. (2007). Effects of biopolymer addition on the dynamic rheology and microstructure of renneted skim milk systems. Journal of Texture Studies, 38(3), 404-422.

Tunick, M. H. (2000). Rheology of dairy foods that gel, stretch, and fracture. Journal of Dairy Science, 83(8), 1892-1898.

Volikakis, P., Biliaderis, C. G., Vamvakas, C., \& Zerfiridis, G. K. (2004). Effects of a commercial oat- $\beta$-glucan concentrate on the chemical, physico-chemical and sensory attributes of a low-fat white-brined cheese product. Food Research International, 37(1), 83-94.

Zisu, B., \& Shah, N. P. (2005). Textural and functional changes in low-fat Mozzarella cheeses in relation to proteolysis and microstructure as influenced by the use of fat replacers, preacidification and EPS starter. International Dairy Journal, 15(69), 957-972. 